\title{
7: 86987215-86777599
}

National Cancer Institute

\section{Source}

National Cancer Institute. 7: 86987215-86777599. NCI Thesaurus. Code C41631.

Physical location of ABCB1_Gene 